\title{
PROJECTS AND SCHOOL
}

\section{Keywords}

Landscape architecture

Intuition

Profession

Discipline

Lessons
Despite being an institutional

publication, $A R Q$ magazine has an

ambiguous condition: it is not the means

for broadcasting the institution to which

it belongs, but neither has it been alien

to the academic debates in which its

existence is framed. The ten projects

offered here represent the diversity of

transfers between the journal and the

school, forming a complex inclusion-

exclusion relationship.

W

hen thinking about the links between $A R Q$

magazine and the School of Architecture UC, an intuitive image appears: through certain projects, the magazine helped establish landscape architecture within the school. Thus, the following text moves between this personal opinion ${ }^{1}$ and a more general framework within which this conjecture should be discussed. Oscillating between a first intuition and different questions and concerns that allowed adjusting the selection, ten projects were chosen.

Now, as a collection of projects and architectural works, the magazine is an odd creature. We are so used to its format and transmission that its strangeness rarely amazes us. The magazine places architectural works between an experimental nature and a state of hypothesis; that is, as projects. Thus, works are doubly removed from reality: first, from their physical reality into an image, and second, from their multiple dimensions to just two. In this physical suspension, not only the reader's imagination comes into play - as he or she must try to understand the work through the information published - but also his or her memory, 
since the reader must link the project to the references the publication refers to. In only a few occasions the project's publication is a work in itself, with its own unity. Inevitably, the question of whether a work should be chosen according to the place it takes within the magazine or its actual feasibility arises.

When grouping projects by themes, different constellations emerge and thus one can ask, how do landscape, architecture and the city appear? How do design and heritage appear? Where are they located and what happens when foreign works are added? One also questions - or would like to understand how specific subjects arise through the gathering of buildings, single-familiy, collective and social housing, schools, exhibitions, and the accustomed topics for studio or graduate.

It is interesting to acknowledge that there are projects that remain as such and other that are transformed into buildings. There are even some that no longer exist. When selecting, we are faced with the dilemma of whether these should be influential projects within architecture or projects that had have an impact on the school. This distinction is partially made. Another differentiation is that one thing is the building itself, which is different from the building and the architect; the building and its time; the building and architectural positions; or, the building and its publication. Hence, it was decided - in general terms - to select the work itself. The major projective dimension of many architects' written ideas has thus not been considered for this selection.

An issue only outlined is what projects or buildings should have been chosen and have not been included. In turn, the question of how to discern between the school's influence on the journal or the journal's influence on the school is an open one. 
Escoger en aquella diversidad es una tarea difícil; sin embargo, cuestionarse más conscientemente esa relación enriquecería la escuela y la revista.

El criterio de selección consistió en no diferenciar entre obra y proyecto; en reconocer aquellas obras notables que, entre otras cosas, moldean la vida cotidiana de la escuela y su campus; en aquellas obras lejanas que, siendo opuestas, constituyen lecciones; $y$, finalmente, en obras que prefiguraron y delinean, en parte, la comprensión de nuestro paisaje y que colaboraron en la formación del Magíster en Arquitectura del Paisaje.

Sintéticamente son lecciones y obras cercanas y notables donde se desarrolla la vida de la escuela, junto a lecciones y obras más distantes y valiosas que polarizan una profesión, y a lecciones y obras que ayudaron a delinear el paisaje como ámbito disciplinar. ARQ
To sum up, the relationship between the works published in the journal and their influence on the school is rich and diverse and, altogether, it is indirect and non-linear. To choose among that diversity is a difficult task; however, consciously questioning that relationship would enrich both the school and the magazine.

The selection criteria consisted of not differentiating between building and project; in recognizing those remarkable works that, among other things, shape the daily life of the school and its campus; in those distant works that, by being opposite, provide useful lessons; and, finally, in works that prefigured and outline, partially, the understanding of our landscape and collaborated in the creation of the Magíster en Arquitectura del Paisaje [Master in Landscape Architecture] program.

In short, these are lessons and buildings - familiar and yet remarkable - where the school's life develops, along with other more distant, valuable lessons and works that polarize a profession, and lessons and buildings that helped to outline landscape as a disciplinary field. ARQ

\section{Notas / Notes}

1 Despite being a mere opinion, its scope goes further than that, since something that is published exerts power and determines a certain imaginary.

\section{Wren Strabucchi}

<wstrabuc@uc.cl> 

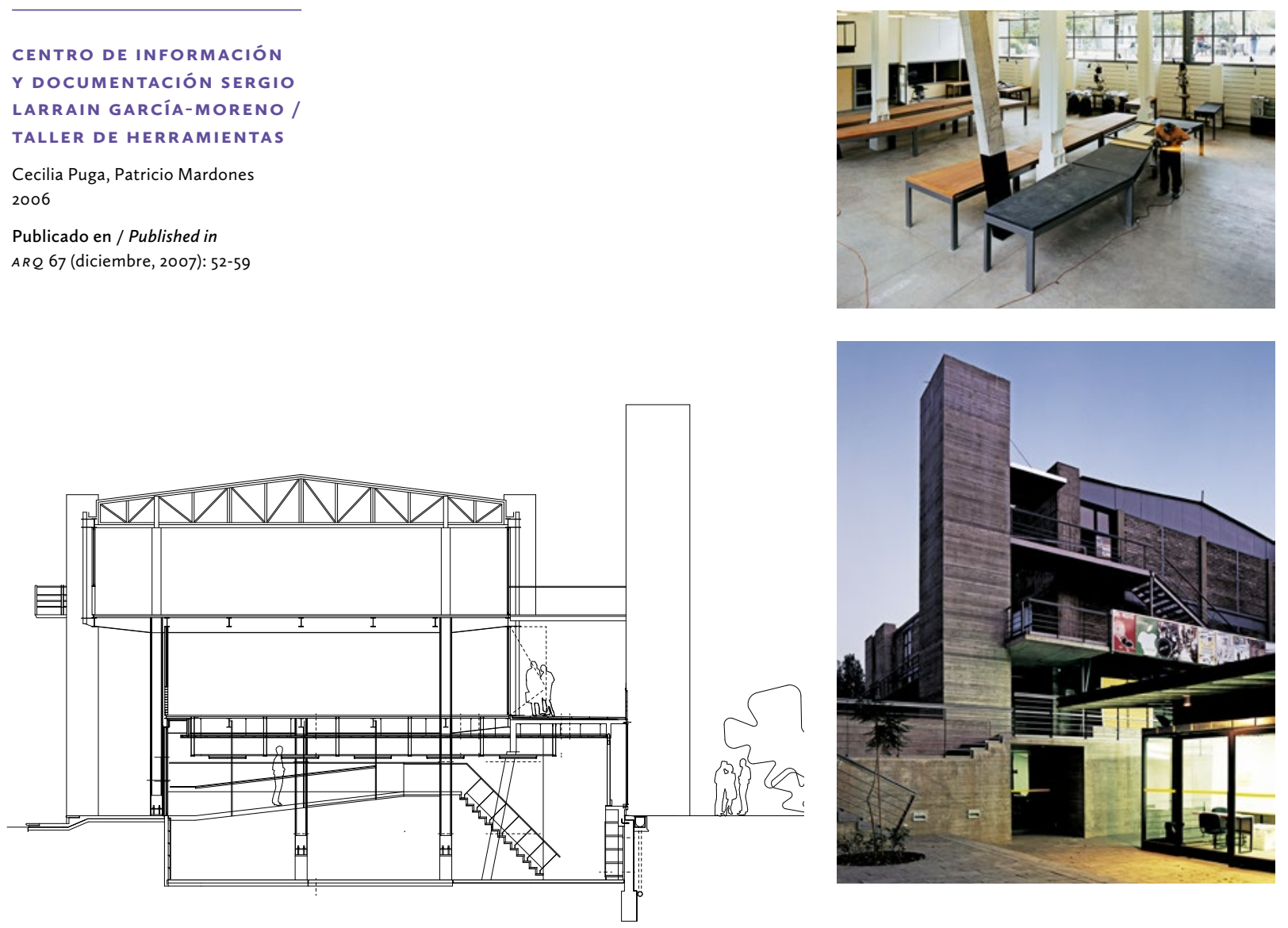

PORTAL LYON

Larrain Murtinho y Asociados
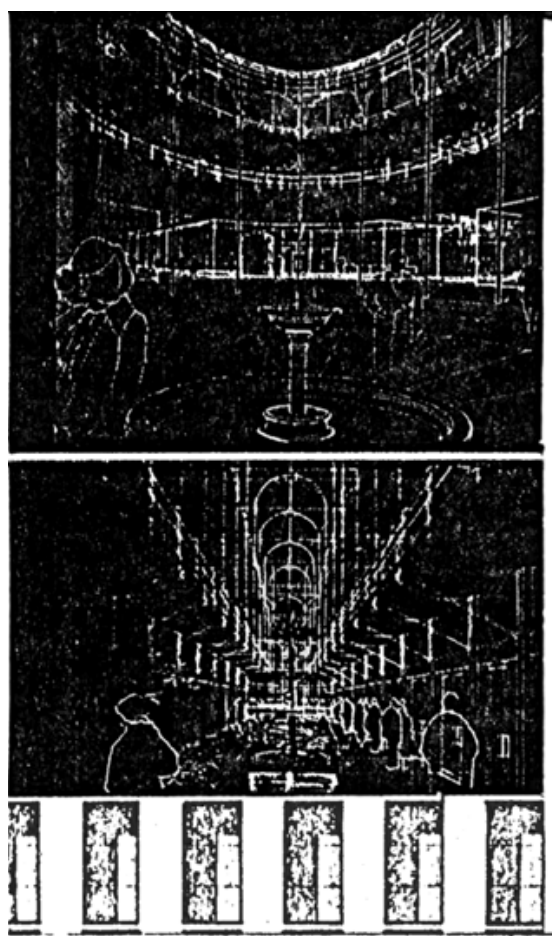
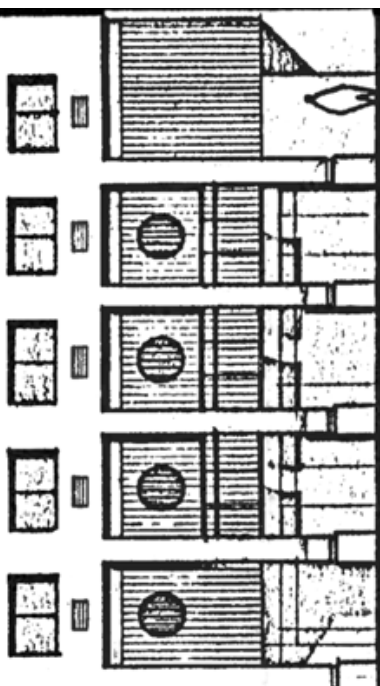

8
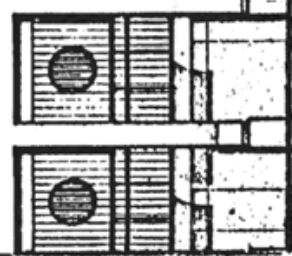

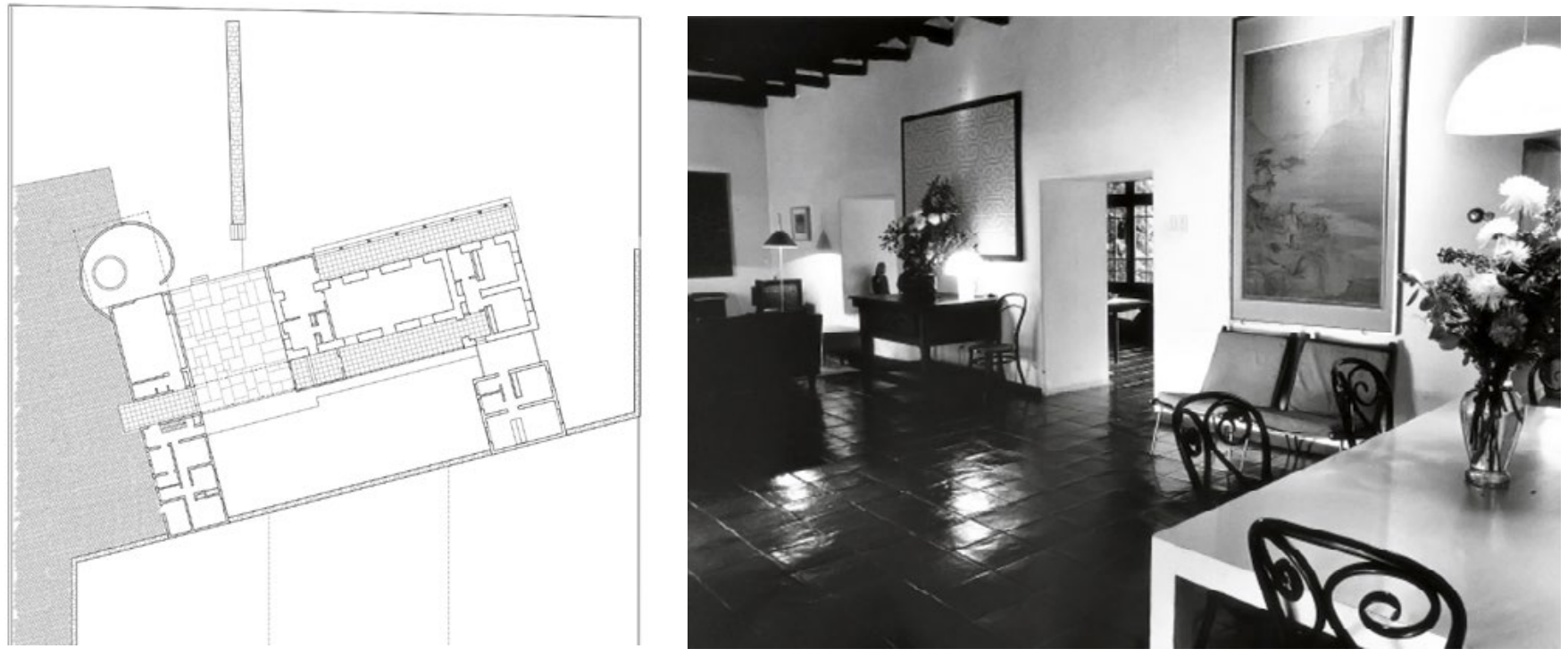

CASA PARA EL POEMA DEL ÁNGULO RECTO

Smiljan Radić

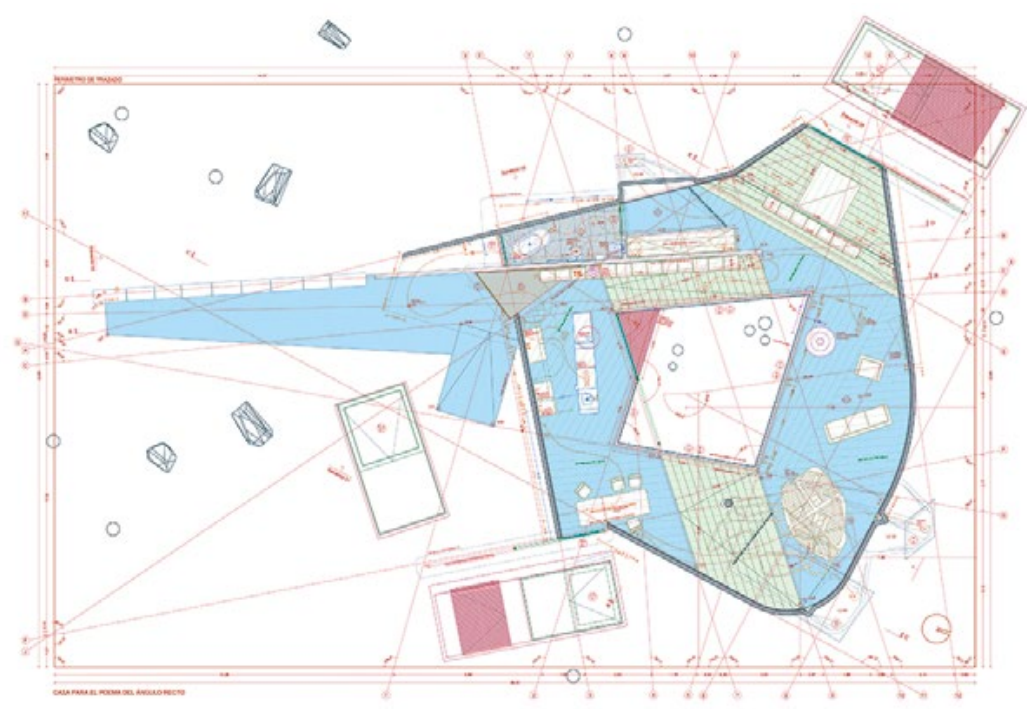

Publicado en / Published in ARQ 82 (marzo, 2005): 68-75

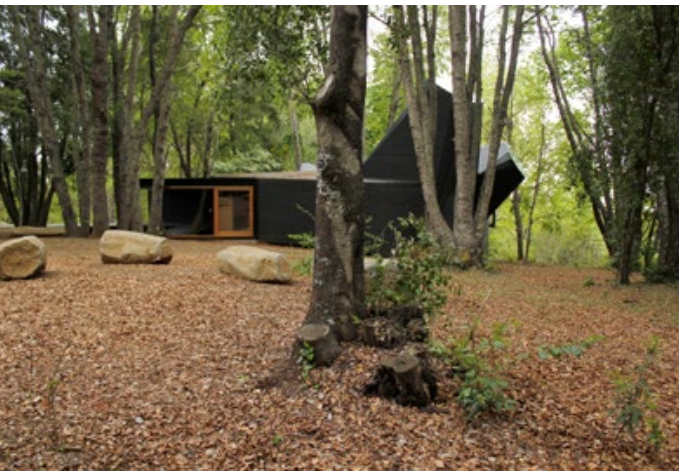



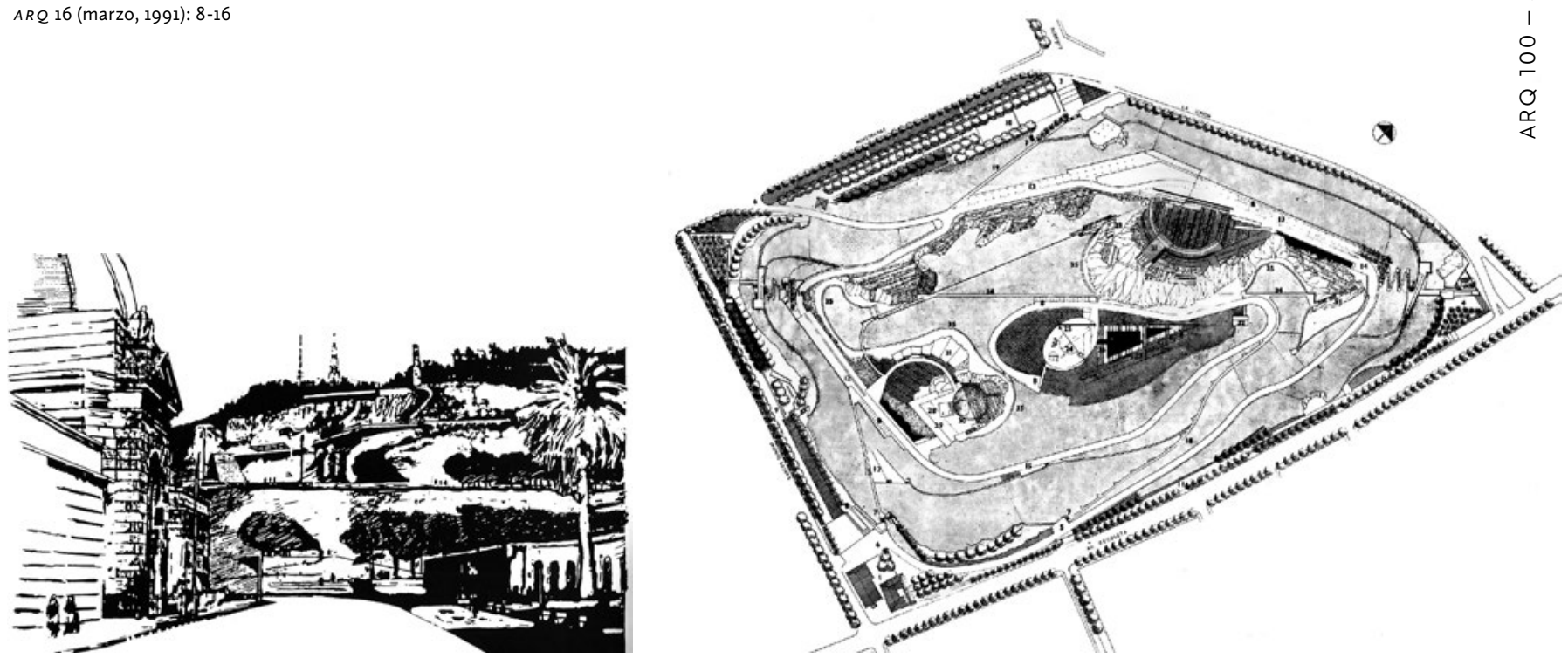

PLAZA DE ARMAS DE SANTIAGO

Rodrigo Pérez de Arce,

Sebastián Bianchi, Leonor

Camaño, Álvaro Salas

Publicado en / Published in

ARQ 39 (agosto, 1998): 46-51
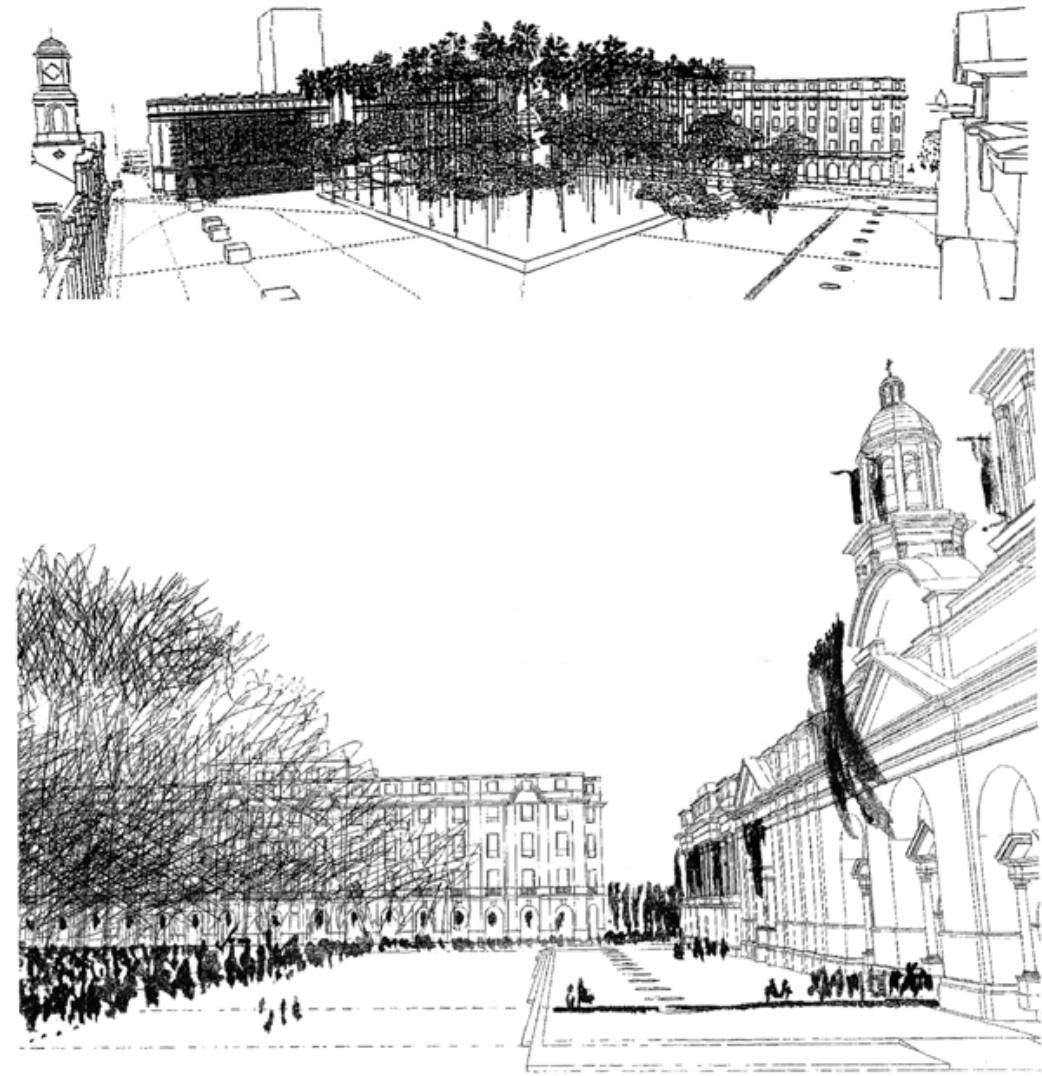
Sandra Iturriaga, Juan Ignacio

Baixas, Francisco Croxatto,

Paulina Ibieta, Francisco

Quintana - Equipo Mapocho 42K

2013

Publicado en / Published in

$A R Q 85$ (diciembre, 2013): $82-87$
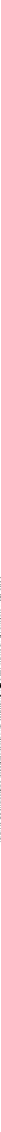

\section{PALACIO PEREIRA}

\section{MiSTORIA DE UNA EFCUPERACIÓN PATRIMONIA}

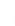
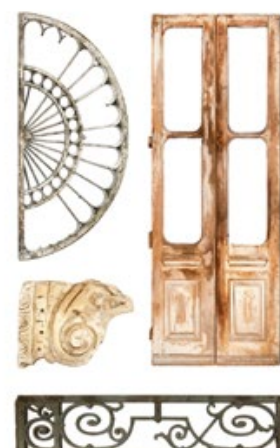

\section{CONCURSO PALACIO PEREIRA}

Cecilia Puga, Paula Velasco, Alberto Moletto 1999

Publicado en / Published in

No publicado en revista $A R Q$

CRISPIANI, Alejandro (ed.). Concurso

Palacio Pereira. Historia de una recuperación patrimonial. Santiago: Ediciones ARQ, enero de 2014: 154-163 
HOTEL EXPLORA

SAN PEDRO

Germán del Sol

1998

Publicado en / Published in ARQ 35 (abril, 1997): 40-43
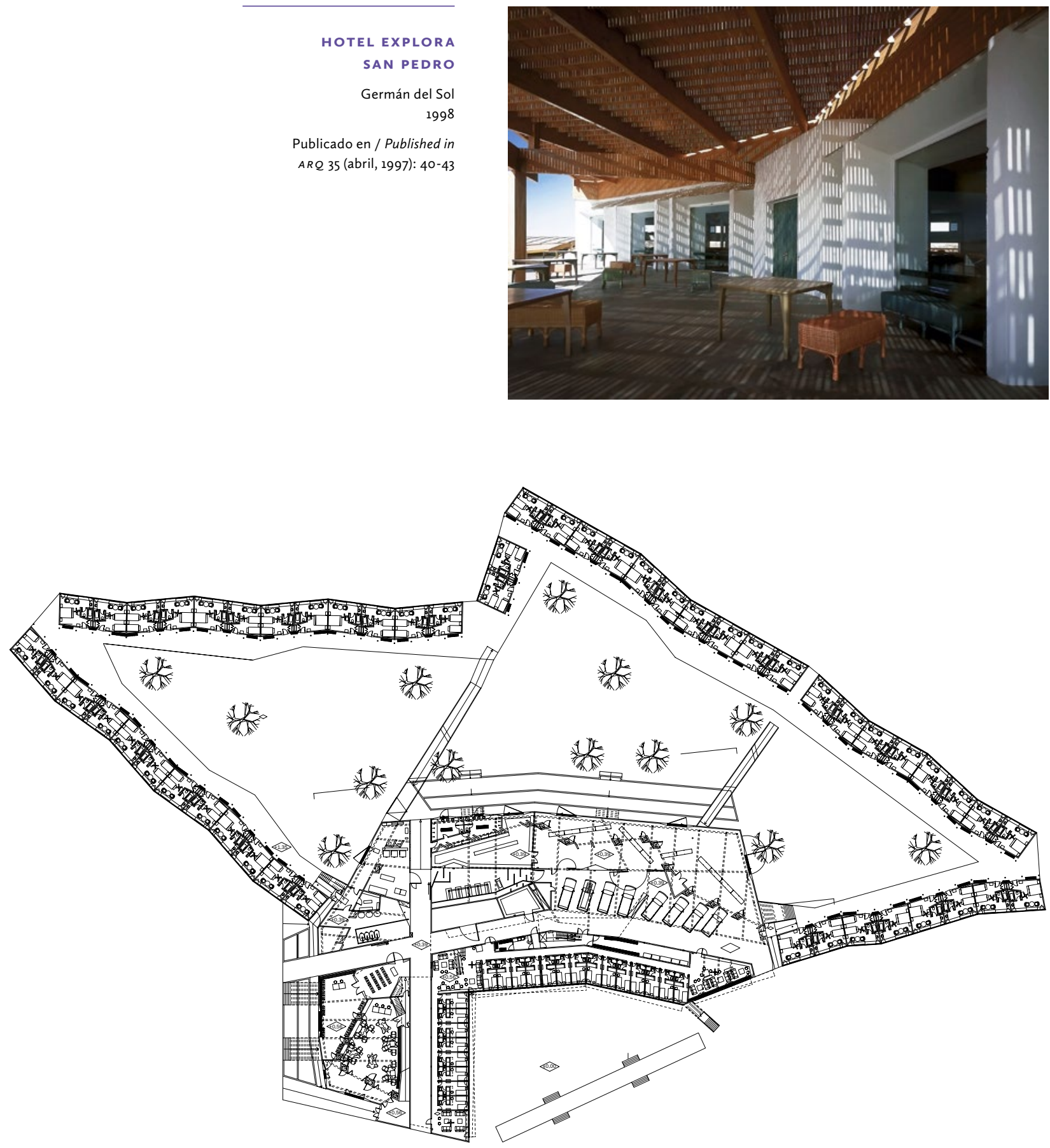

RECUPERACIÓN DE GRANDES

VACÍOS URBANOS.

LA FRONTERA INTERIOR DE

SANTIAGO. PROYECTO DE TÍTULO

Roberto Moris, Marcelo Reyes

1999

Publicado en / Published in

No publicado en revista $A R Q$ / Not published

in $A R Q$

Nota / Note: este proyecto no fue

publicado en ARQ habiendo tenido los

méritos / this project was not published in

$A R Q$ having the merits for it. 